\title{
Dietary influence on a desirable fatty acid composition in milk from dairy cattle
}

\author{
J. Voigt and H. Hagemeister
}

\author{
Research Institute for the Biology of Farm Animals, \\ Research Unit Nutritional Physiology "Oskar Kellner" \\ Wilhelm-Stahl-Allee 2, D-18196 Dummerstorf. Germany
}

\begin{abstract}
Milk components, with respect to the potential for improving health and the prevention of health problems, are intermediate products of the biohydrogenation of poly-unsaturated fatty acids in the rumen of cattle. Dairy products are a major source of conjugated linoleic acids (CLA) in the human diet. It has been demonstrated that CLA can suppress carcinogenesis, modulate the immune system, and can have an anti-obesity effect, while reducing atherogenesis and diabetes. Controlled intervention studies showed that trans fatty acids have a significant adverse effect on the LDL cholesterol level. The aim must therefore be to have a high content of poly-unsaturated fatty acids and CLA in milk, while concurrently having a low content of trans -9 and trans $-10 \mathrm{C}_{18: 1}$ fatty acids. The high correlation between CLA and the sum of all trans fatty acids of $r=0.88$ in milk fat demonstrates that this goal is not easy to achieve. New fecding strategies for lactating ruminants in which an independent regulation of the different $\mathrm{C}_{18: 1}$ isomers is considered as pasture feeding, concentrate to roughage management, use of protected plant oils and use of milk fat low-sensitive cows have to be developed.
\end{abstract}

KEY WORDS: dairy cattle, conjugated linoleic acid, trans fatty acids, poly-unsaturated fatty acids

\section{MILK FAT DEPRESSION}

The modern dairy cow has been freed from the negative controls on the suckled animal (Cant et al., 1999). The milk precursor concentration in blood, in relation to mammary secretory cell number, determines the rate of milk synthesis. When high concentrate diets are fed, the rate of milk fat synthesis can decrease by $50 \%$ or more (Davis and Brown, 1970; Sutton, 1989). In addition, several other dietary manipulations, including dietary fats that are reactive in the rumen, forages with 
small particle size, lush pasture, and ionophores, result in, to varying degrees, decreased milk fat yield. The actual mechanisms involved in milk fat depression have not been fully elucidated, but several theories have been proposed. Most of the theories involve changes in rumen fermentation and fermentation mechanisms, which are postulated to result in a shortage of lipid precursors in the mammary gland (Hagemeister, 1990). The glucogenic-insulin theory of milk fat depression, which occurs for cows consuming a high concentrate, low roughage diet, is based on insulin altering nutrient partitioning to specific tissues by affecting rates of utilization, uptake, or release. Stimulation of lipogenesis and inhibition of lipolysis in adipose tissue are well documented (Bauman and Currie, 1980) but specific investigations on the influence of chronic hyperinsulinaemia on milk fat synthesis offered no support for the role of insulin on milk fat depression (Griinari et al., 1997). In addition to a shortage of lipid precursors in the blood it is possible that metabolites which are produced in the rumen can directly inhibit mammary synthesis of milk fat. Poly-unsaturated fatty acid intake is correlated with the trans fatty acid content of duodenal chyme, and trans fatty acid in milk fat with the extent of milk fat depression (Wagner et al., 1999). The trans-10, cis-12 isomer of conjugated linoleic acid (CLA) affects milk fat synthesis, causing as much as a $40 \%$ reduction (Baumgard et al., 2000). The de novo synthesized fatty acids are extensively reduced and the change in ratio of unsaturated to saturated fatty acids in milk fat demonstrate an alteration in delta ${ }^{9}$-desaturase in the mammary gland. The concentrations of glucose, nonesterified fatty acids, insulin and IGF 1 in blood plasma are minimally affected, demonstrating a change in the capacity of the mammary gland in the synthesis of fatty acids. These metabolites originate from a combination of low $\mathrm{pH}$ in the rumen and the presence of unsaturated fatty acids in the ration. They are not only of interest in the regulation of milk fat synthesis but also of interest in the fat metabolism of human.

An increase in the proportion of milk fat that is liquid at $5^{\circ} \mathrm{C}$ improves spreadability at the respective temperature (Banks, 1991). For human nutrition the effect of oleic acid (cis-9 $\mathrm{C}_{18: 1}$ ) on serum lipids and lipoproteins is demonstrated in a meta-analysis of 27 trials by Mensink and Katan (1992). Replacement of saturated by unsaturated fatty acids produces a more favourable lipoprotein profile than does replacement by carbohydrates. Replacing $10 \%$ of energy in the form of saturated fatty acids by carbohydrates would lower LDL cholesterol by $13 \mathrm{mg} / \mathrm{dL}$ and HDL by $5 \mathrm{mg} / \mathrm{dL}$, whereas replacement by mono-unsaturates causes a reduction of $15 \mathrm{mg}$ / $\mathrm{dL}$ in $\mathrm{LDL}$ cholesterol and $1 \mathrm{mg} / \mathrm{dL}$ in HDL cholesterol. Each $1 \mathrm{mg} / \mathrm{dL}$ increment in LDL cholesterol causes an increase in coronary risk of $1 \%$. Epidemiological observations also show an increase of $2-3 \%$ in risk for each $1 \mathrm{mg} / \mathrm{dL}$ decrease in HDL cholesterol. Dairy products produced through substitution of saturated fatty acids by mono-unsaturated fatty acids have been shown successfully to reduce blood cholesterol levels in human volunteers (Noakes et al., 1996). In addition to 
the change in cholesterol ester and lipoprotein content in the blood, the feasibility of using an oleate-rich diet to reduce the susceptibility of low-density lipoprotein to oxidative modification in humans has been considered (Reaven et al., 1991).

Unsaturation of the respective dominant fatty acid in a calcium salt of diets for dairy cows has a negative linear effect on milk fat percentage (Choinard et al.,

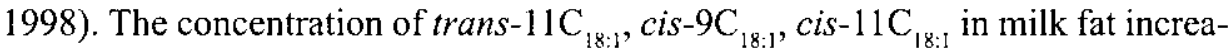
ses linearly as the amount of calcium salts in rape seed oils with high $\mathrm{C}_{18: 1}$ content in the diet increases. The decreased milk fat percentage observed suggests that the proportion of $\mathrm{C}_{18}$ fatty acids is not sufficient to compensate for a decrease in fatty acid synthesis. Moreover, the activity of acyltransferase that is responsible for the formation of triacylglycerols in the mammary gland might be inhibited by trans$\mathrm{C}_{18: 1}$ fatty acids (Gaynor et al., 1994). The changes in fatty acid composition in response to dietary supplements of fat appear to depend on the stage of lactation. Grummer (1991), after reviewing the literature on this subject, suggested that the transfer efficiency of plasma fatty acids to mammary tissue decreases as lactation progresses. A greater response of milk fat composition to dietary supply of unsaturated fatty acids may therefore be expected in early lactation compared to late lactation.

\section{POLY-UNSATURATED FATTY ACIDS}

There is considerable evidence to suggest that polyunsaturated fatty acids of marine origin have beneficial effects against cardiovascular disease, including atherosclerosis and thrombosis (Herold and Kinsella, 1986). Plant polyenes, such as linoleic and linolenic acid, in the diet can reduce the LDL and total cholesterol content of the blood as demonstrated by Mensink and Katan (1992) in Figure 1.

The conversion of alpha linolenic acid to the long chain omega-3 polyunsaturated fatty acids, eicosapentaenoic acid (EPA) and docosahexaenoic acid (DHA), is low in humans (Chan et al., 1993). This conversion may be further suppressed due to inhibition of the delta-6-desaturase enzyme, by a high intake of linoleic acid. Contrary to early reports, Williams (2000) demonstrated based on new literature that alpha linolenic acid can increase the tissue level of EPA (but not DHA). This increase is associated with altered platelet aggregation, blecding tendency, and the prevention of arrhythmia of the heart.

Grass is the main source of linolenic acid in the ration of cows. The amount of linolenic acid absorbed from grass is higher as from other forages. Therefore as demonstrated from a representative study in Germany (Precht and Molkentin, 1998) the content of linolenic acid in milk fat following turnout to pasture increases two times ( $1.1 \mathrm{vs} 0.55$ ). Among the non-forage feeds, linseed is the only one which has significant amounts of $\mathrm{C}_{18: 3}$, which represents more than $50 \%$ of fatty acids. In our 


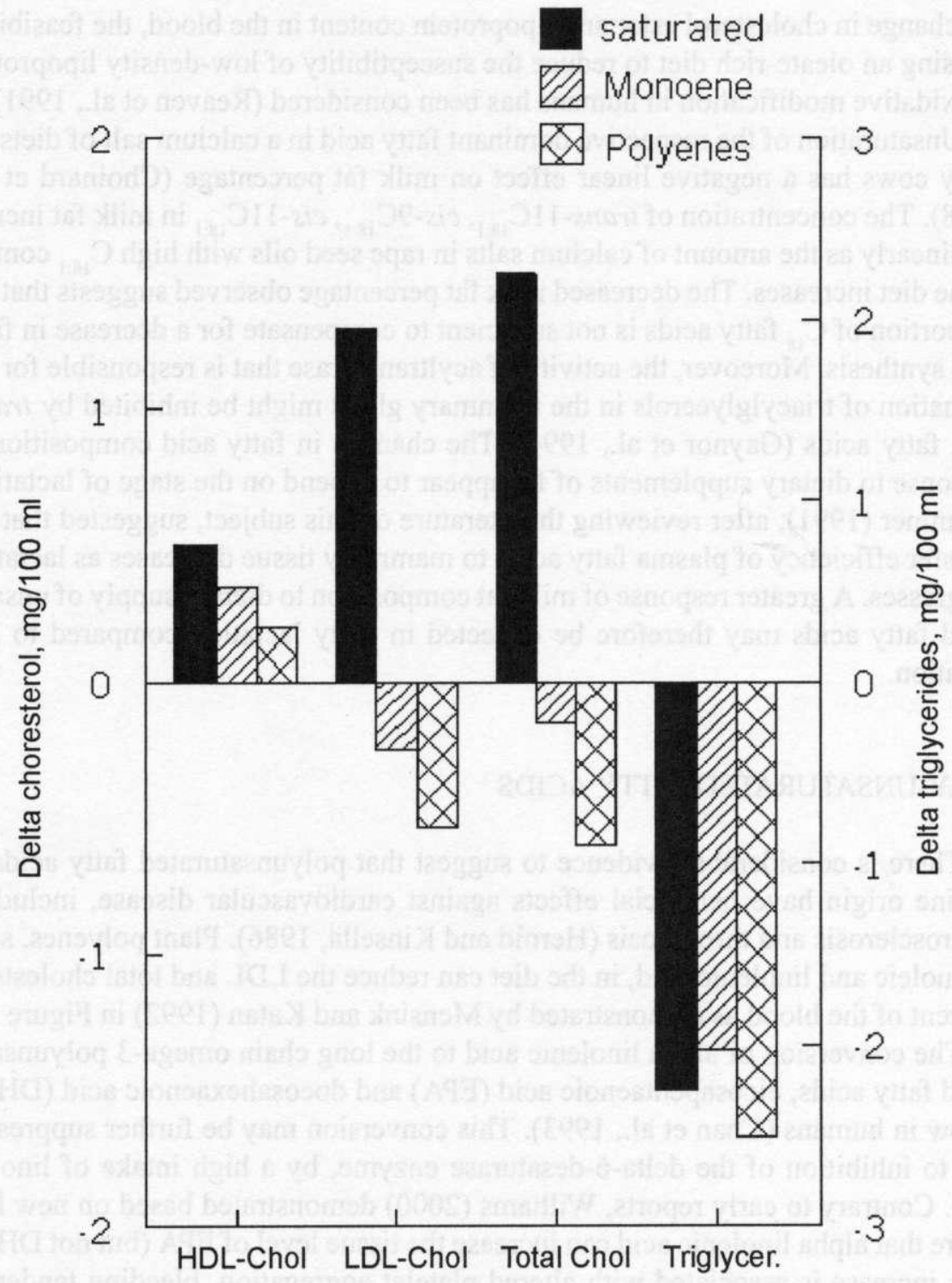

Figure 1. Changes of serum lipoprotein lipid levels if $1 \%$ of energy is provided as fatty acids instead of (previous) starch. Adapted from Mensink and Katan (1992) 
study (Hagemeister et al., 1991) we have analysed the effect of linseed or linseed oil, which were infused directly into the abomasum, on milk fat composition. The effect of ungrounded linseed grain on the content of linolenic acid was very low. A high transfer of $40 \%$ for linolenic acid which was infused into the abomasum demonstrates, that by sufficient protection of this acid from rumen hydrogenation, a high content of poly-unsaturated fatty acids in milk fat can be obtained. As in humans, as it is in cows, the conversion of alpha linolenic acids to long chain omega-3 polyunsaturated fatty acids is very low at only 1.0\% (Hagemeister et al., 1991).

An increase in EPA and DHA in milk fat can be achieved by the use of specific fish oils. Under these conditions the fish oil in the ration of cows has to be protected. When fish oil is unprotected, the transfer efficiency of EPA and DHA in milk fat is very low. Fish oil also results in a strong decrease in total fat secretion, as described as low milk fat syndrome. In our trials fish oil infusion into the abomasum ( 220 or $420 \mathrm{~g} /$ day) resulted in an EPA and DHA content of 4 and $6 \%$ in milk fat, respectively. The peak transfer into the milk was up to $60 \%$. New investigation by Chilliard et al. $(1997,1999)$ who infused the oil into the duodenum of the cows, demonstrated a transfer efficiency into milk of EPA and DHA of 20 and $18 \%$, respectively. The concentration in milk fat was detected at up to $2 \mathrm{~g}$ in $100 \mathrm{~g}$ of fatty acids. Despite the positive effect of fish oil on the amount of polyunsaturated fatty acids in milk and milk products, this feeding practice will be of limited interest. We have not been able to avoid an undesirable oxidative flavour of milk and milk fat by the additional supply of different kinds of antioxidants (Hagemeister et al., 1991). With antioxidants, different in the water and lipid solubility supplied into the feed (into the rumen or the abomasum as into the milk) the milk flavour decreased quickly with the time after milking. Comparable results have been presented by Lacasse et al. (1998).

\section{CONJUGATED LINOLEIC ACIDS (CLA)}

CLA represent a mixture of positional and geometric isomers of octadecadienoic acid $\left(\mathrm{C}_{18: 2}\right)$ with conjugated double bonds. Food products from ruminants, mainly dairy products, are a major source of CLA in the human diet. CLA have been demonstrated to have a wide range of positive health effects in experimental models. These include suppression of carcinogenesis (Ha et al., 1990; Ip et al., 1994; Belury, 1995), modulation of the immune system (Cook et al., 1993), an antiobesity effect (Park at al., 1997) and a reduction in atherogenesis (Nicolosi et al., 1993) and diabetes (Houseknecht et al., 1998). Whilst animal and cell culture studies support the possibility of remarkable anticarcinogenic actions of CLA, whether such effects are present in humans and whether variations in human dietary intakes of CLA containing dairy products can explain variations in susceptibility to cancer 
remains to be determined. Williams (2000) remarked that the data from a report of the protective effects of dairy products against human breast cancer in a recent prospective study are consistent with the mentioned results from animal models. The specific CLA isomer(s) responsible for these various biological effects has not been clearly established, although cis-9, trans-11 CLA is thought to be the key in the anti-carcinogenic effect (Ha et al., 1990; Ip et al., 1991). The fatty acid trans-11 $\mathrm{C}_{18: 1}$, which is the main trans fatty acid in milk fat, could have a higher value for the state of health, because it can be transformed to cis-9, trans-11 CLA by the delta9 desaturase in the tissue of the mammary gland, as demonstrated in cows (Griinari et al., 2000) and mice (Santora et al., 2000). Thus, increasing the concentration of CLA in milk may be beneficial to health and may enhance the consumption of dairy products. But, while there is good evidence for anti-carcinogenic action of CLA from animal and cell studies, other benefits such as anti-lipogenic and antiatherogenic effects are less well substantiated and will be found only at higher concentrations as demonstrated by Williams (2000) in Table 1.

TABLE 1

Human dietary equivalents of conjugated linoleic acid levels shown to produce protective effects in animals (Williams, 2000)

\begin{tabular}{lcc}
\hline Action & $\begin{array}{c}\text { Active dose level } \\
\text { in animals }\end{array}$ & $\begin{array}{c}\text { Equivalent diet level } \\
\text { in humans }\end{array}$ \\
\hline Anti-carcinogen & $0.04 \mathrm{~g}^{-\mathrm{kg}^{-1} \text { body weight }}$ & $3.0-3.5 \mathrm{~g} \cdot \mathrm{d}^{-1}$ \\
Anti-lipogenic & $0.05 \%$ diet & $15-20 \mathrm{~g} \cdot \mathrm{d}^{-1}$ \\
Anti-atherogenic (carly lesions) & $5 \mathrm{~g} \cdot \mathrm{kg}^{-1}$ & $400 \mathrm{~g} \cdot \mathrm{d}^{-1}$ \\
\hline
\end{tabular}

Dietary CLA supplements (mixture of isomers) have been shown to decrease body fat accretion in several species of growing animals, including mice (Park et al.,1997) and pigs (Dugan et al., 1997). However, in a new investigation on mice (Dhima et al., 2000) no influence of CLA enriched in cheese on body composition could be found. Feeding synthetic CLA to these mice reduced body fat by $54 \%$ compared with mice fed naturally enriched high CLA cheese. In this connection the investigation of Lin et al. (2001) may be mentioned, which indicate that CLAs differ in regulation heparin-releasable lipoprotein lipase activity and trans-10, cis12 CLA appears to be more effective than cis-9, trans-11 CLA.

For rearing of young animals the immunological effect of CLA could be of interest. Investigations of Bassaganya-Riera et al. (2001) demonstrated the immuno-modulatory effects of CLA mixtures of cis-9, trans-11 and trans-10, cis-12 isomers. CLA induced a linear increase in percentage of $\mathrm{CD} 8^{+}$lymphocytes in piglets. The data suggest that CLA supplementation preceding a disease challenge could have prevented disease-associated growth suppression. But up to now no 
conclusive explanation have been found of the reacting mechanism (steps of eicosanoid synthesis) and the ability of different isomers of CLA to effect the sensitivities to eicosanoids. Recent reports suggested that CLA did not have any antioxidant property (van den Berg and Cook, 1995).

From the different isomers of $\mathrm{C}_{18: 2}$ in milk (Figure 2) the cis-9, trans-11 $C_{18: 2}$ represents almost $90 \%$ of the total CLA isomers (Griinari and Bauman, 1999; Parodi, 1999). This fatty acid is an intermediate product of the biohydrogenation of linoleic acid by the rumen bacteria Butyrivibrio fibrisolvens (Kepler and Tove, 1967) and possibly other species. Lipid biohydrogenation in the rumen is affected by the type and amount of fatty acid substrate (Noble et al., 1974), the forage to grain ratio (Gerson et al., 1985), and the nitrogen content of the diet fed to the ruminants (Gerson et al., 1983). Contrary to high concentrations of trans fatty acids and low concentrations of CLA in ruminal content, relatively more CLA is found in milk fat. From these results Griinari and Bauman (1999) concluded that ruminant mammary gland and adipose tissues are able to synthesise cis-9, trans-11 CLA from trans $-11 \mathrm{C}_{18: 1}$.
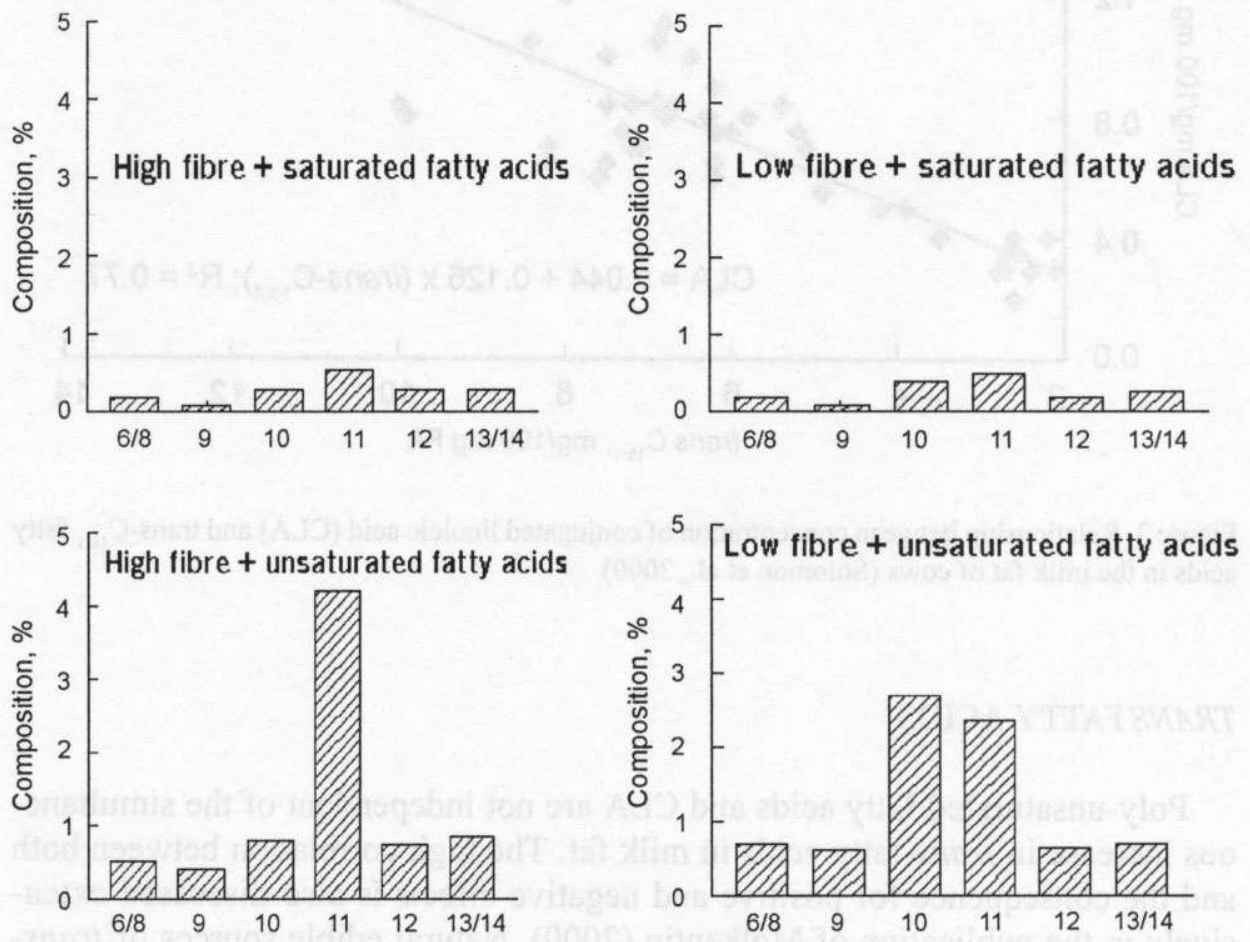

Figure 2. Effect of dietary fibre and added fat on trans-octadecenoic acid isomers (Griinari et al., 1998) 
$33 \%$ of the trans $-11 \mathrm{C}_{18: 1}$ taken up by the mammary gland is desaturated to cis-9, trans-11 CLA. Between 61 and $78 \%$ of the milk fat CLA are of endogenous origin (Corl et al., 2000). This could explain the high correlation between these two acids in milk (Figure 3; Solomon, 2000). In addition, CLA can also be absorbed with at a $30 \%$ efficiency from the digestive tract and immediately used by the mammary gland (Chouinard et al., 1999). Precht and Molkentin (1998) reported a variation of 4.0 to $12.5 \mathrm{mg}$ of CLA/g of fat in the milk of cows dependent on barn or pasture feeding. The technical treatment of rape seed (oil, whole, meal from rape seed or rape seed pellets) resulted in a variation of 7.0 to $13 \mathrm{mg}$ CLA/g milk fat.

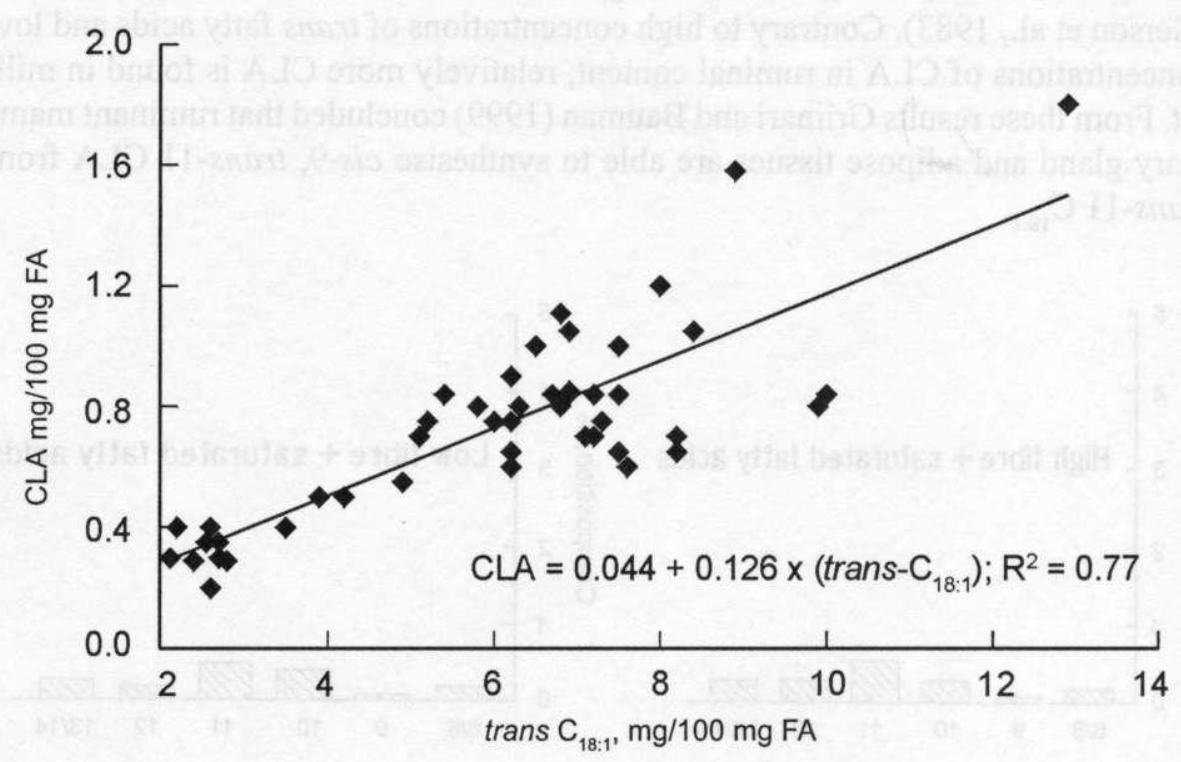

Figure 3. Relationship between concentration of conjugated linoleic acid (CLA) and trans- $\mathrm{C}_{18: 1}$ fatty acids in the milk fat of cows (Solomon et al., 2000)

\section{TRANS FATTY ACIDS}

Poly-unsaturated fatty acids and CLA are not independent of the simultaneous increase in trans-fatty acids in milk fat. The high correlation between both and the consequence for positive and negative effects is also discussed extensively in the publication of Molkentin (2000). Natural edible sources of transacids for humans, mainly trans- $\mathrm{C}_{18: 1}$ acids, are restricted in practice to ruminant fats. Trans-fatty acids, present in partially hydrogenated vegetable oils are ques- 
tioned as to their harmfulness to health. Recent reanalysis of the data from controlled intervention studies showed a significant adverse effect on LDL cholesterol level for the sum of all trans fatty acids in the meals. With each $1 \%$ increase of trans-fatty acids in dietary energy an increase of $1 \mathrm{mg} / \mathrm{dL}$ LDL in blood was found (Mensink and Zock, 1998). Williams (2000) concluded that there is modest evidence from experimental studies in humans and epidemiological dietary data to suggest that elevated levels of trans-fatty acid intake may increase the risk of coronary heart disease.

Up to now these trials do not give a clear picture of differences in the effect between the isomers of trans $\mathrm{C}_{18: 1}$. Rather, it does raise questions as to possible differences between the natural trans $-11 \mathrm{C}_{18: 1}$ (vaccenic acid) derived from ruminal metabolism and the technological originated trans- $9 \mathrm{C}_{18: 1}$ (elaidic acid) in the physiological reaction of a foodstuff. It is also possible that other isomers at lower concentrations may be of negative or positive influence. Only the sub-analysis in a group of nursing women showed an increased risk of coronary heart disease for trans isomers from vegetable fats, but not from those from animal fats (Willett et al., 1993) The quantity of trans-9 and trans-10 $\mathrm{C}_{18: 1}$ fatty acids, but not that of trans-11 $\mathrm{C}_{18: 1}$ fatty acids, in different meals, can be positively correlated with the risk of coronary heart disease (Hodgson, 1996). Risk of coronary heart disease included biscuits and cakes, but not dairy products (Willett et al., 1993). Based on disturbances in the metabolism it is concluded that vaccenic acid compared to elaidic acid has a lower effect on lipoprotein secretions from intestinal caco-2-cells (van Greevenbroek et al., 1998). The B-oxidation of vaccenic acid is faster in rat heart mitochondria (Lawson and Kummerow, 1979). In human skin fibroblasts the delta-5 desaturase is not inhibited by vaccenic acid, contrary to elaidic acid (Rosenthal and Doloresco, 1984). In a trial with mice it has been demonstrated that vaccenic acid is used for the synthesis of CLA, but not elaidic acid (Santora and Palmquist, 2000). However, Salminen et al. (1998) demonstrated that based on an increase of CLA in human serum, trans fatty acids from partially hydrogenated vegetable oil may form CLA. By comparing the effect of a 4-day infusion of $c i s-9$, trans-11 and trans-10, cis-12 $\mathrm{C}_{18: 2}$ in mice Baumgard et al. (2000) demonstrated that only the cis-12 form is responsible for the inhibition of milk fat synthesis. The most predominant CLA in milk, cis-9, trans-11 $\mathrm{C}_{18: 2}$, is not an inhibitor.

If we would apply the results obtained in model trials to humans, the aim would be to reduce preferably the trans-9 and trans-10 $\mathrm{C}_{18: 1}$ fatty acids in milk fat. A negative affect of trans- $11 \mathrm{C}_{18: 1}$ could perhaps be reduced if, as in ruminants, $33 \%$ is converted to CLA. If the negative milk fat syndrome is also independent from the synthesis of trans-11 $\mathrm{C}_{18: 1}$ fatty acid synthesis in the rumen, the general consideration of trans-fatty acids is outdated. Related to the spreadability of butter, the limits of a maximal content of $7 \%$ of total fatty acids results in so called summer butter (Precht and Molkentin, 1997) and have to be taken in account. 


\section{INCREASE OF CONJUGATED LINOLEIC ACID IN MILK FAT WITHOUT EXCEEDING LIMITS FOR TRANS-9 AND TRANS-10 FATTY ACIDS}

To have milk fat with a high content of unsaturated fatty acids and CLA, but at the same time a low content of trans-9 and trans-10 $\mathrm{C}_{18: 1}$ has been a major research goal. An extremely high correlation between CLA and the sum of all trans-fatty acids of $r^{2}=0.96$, based upon 100 milk fats selected for a great variation in composition (Precht and Molkentin, 1998), and of $\mathrm{r}^{2}=0.77$ (Figure 3) on the basis of different investigations (Solomon et al., 2000), has demonstrated that this goal is not easy to arrive at. But Chilliard et al. (2000) demonstrated, that there are independent regulatory mechanisms that give the chance to increase CLA without exceeding the maximal concentration of specific trans-fatty acids in milk fat. The aim now is to develop new feeding strategies for lactating ruminants (Table 2) in which an independent regulation of the different $C_{18: 1}$ has been considered. Possible ways to meet this goal include pasture feeding (Dhiman et al., 1999), concentrate to roughage management (Jiang et al., 1996; Griinari et al., 1998), and the use of protected plant oils and the use of milk fat insensitive cows (McNamara et al., 1995; Kclly et al., 1998). From the literature we conclude that the supply of canola oil compared to soya or linseed oil in the ration increases CLA in milk relatively more than trans fatty acids (Table 3 ).

TABLE 2

Effects of dietary factors on milk fat CLA content in dairy cows (literature review ${ }^{3}$ from Chilliard et al., 2000)

\begin{tabular}{|c|c|c|}
\hline $\begin{array}{l}\text { Low values } \\
(0.2-0.8 \%)\end{array}$ & $\begin{array}{c}\text { Medium values } \\
(0.8-1.6 \%)\end{array}$ & $\begin{array}{l}\text { High values } \\
(>1.6 \%)\end{array}$ \\
\hline Maize silage & Fresh pasture/young grass & Rape seed oil ${ }^{c}$ \\
\hline Grass silage/hay/pasture & Low fibre diets & Soyabean oil ${ }^{\mathrm{c}}$ \\
\hline $\begin{array}{l}\text { Animal or vegetable } \\
\text { saturated fats }\end{array}$ & Restricted feeding & Sunflower oil ${ }^{c}$ \\
\hline Raw soyabcans & Extruded soyabeans & Linseed oil \\
\hline Micronized soyabeans & Pcanut oil & $\begin{array}{l}\text { Calcium salts of soyabean } \\
\text { and linseed oils }\end{array}$ \\
\hline $\begin{array}{l}\text { Soyabeans treated by heat } \\
\text { processing }\end{array}$ & Rape seed oil ${ }^{b}$ & Fish oils \\
\hline $\begin{array}{l}\text { Extruded soyabeans or } \\
\text { cottonseeds }\end{array}$ & Soyabean oil ${ }^{b}$ & \\
\hline Dietary buffers & $\begin{array}{l}\text { Linseed oil } \\
\text { Calcium salts of rape seed oil } \\
\text { Ionophores (transient?) }\end{array}$ & \\
\hline
\end{tabular}


Griinari et al. (1998) demonstrated (Figure 2) that unsaturated fatty acids from maize oil increase eight-fold the trans-11 $\mathrm{C}_{18: 1}$ fatty acid content in milk fat of control $\left(60 \%\right.$ forage) feeding and seven-fold the trans $-10 \mathrm{C}_{18: 1}$ in milk fat depressing rations ( $20 \%$ forage). A corresponding increase in CLA was observed with a supply of maize oil (Piperova et al., 2000). The high concentrate ration increased ten-fold the trans-10, cis-12 $\mathrm{C}_{18: 2}$ fat and three-fold the trans-7, cis-9 CLA in milk while the cis-9, trans-11 CLA isomer decreased during milk fat depression. These results agree with the hypothesis of Baumgart et al. (2000), that increases in the trans-10 isomer of $\mathrm{C}_{18: 1}$ and not trans -11 is a consistent marker of milk fat decrease by low fibre diet.

TABLE 3

Milk composition of Holstein cows fed calcium salts of canola, soya or linseed oils (Chouinard et al., 1998; Desilets et al., 2000; Dhiman et al., 2000)

\begin{tabular}{llcccc}
\hline & & \multicolumn{4}{c}{ Treatment } \\
\cline { 3 - 6 } & & $\begin{array}{c}\text { control diet } \\
\mathrm{C}\end{array}$ & $\begin{array}{c}\mathrm{C}+4 \% \\
\text { canola }\end{array}$ & $\begin{array}{c}\mathrm{C}+4 \% \\
\text { soya }\end{array}$ & $\begin{array}{c}\mathrm{C}+5 \% \\
\text { linseed }\end{array}$ \\
\hline Dictary ether extract, & $\%$ of DM & 3.48 & 6.0 & 5.89 & 5.27 \\
Milk yield, & $\mathrm{kg} /$ day & 35.9 & 36.2 & 37.0 & 38.8 \\
Milk fat, & $\%$ & 4.05 & 2.67 & 2.98 & 3.56 \\
trans-11 & $\mathrm{mg} / \mathrm{g}$ fat & 1.84 & 8.42 & 12.59 & 10.18 \\
CLA $^{1}$, & $\mathrm{mg} / \mathrm{g}$ fat & 6.5 & 17.1 & $20.0^{2}$ & $17.0^{3}$ \\
\hline
\end{tabular}

${ }^{1}$ CLA $=$ Conjugated Linoleic Acid

${ }^{2} \mathrm{C}+3.3 \%$ soya

${ }^{3} \mathrm{C}+4.4 \%$ linseed

In our studies (Precht et al., 2001) we used high-yielding dairy cows with a daily milk production of about $40 \mathrm{~kg}$ and fed one group with a ration high in starch as a control group and fed the other group a ration high in protected fat. The utilizable protein was the same in both groups (Table 4). The milk production in the fat feeding group from the $4^{\text {th }}$ week was higher, while the fat content of the milk only in the $10^{\text {th }}$ and the $11^{\text {th }}$ week of lactation lower. As well, no low milk fat syndrome was observed. The CLA content in the $13^{\text {th }}$ and $14^{\text {th }}$ week of lactation in the fat group was twice as high as in the control group (Figure 4 ) nearly paralleling $(\sim 15 \%)$ to the content of linoleic acid.

All trans fatty acids increased nearly at the same percentage of $100 \%$ (Figure 5), while the relative increase in percentage of all trans fatty acids was nearly the same. All $\mathrm{C}_{18: 1}$ isomers showed the same change. From this trial we can conclude that it is possible to increase the content of polyunsaturated and conjugated linoleic acid in milk fat of high yielding dairy cows without low milk fat syndrome occuring. But specific trans fatty acids have not been reduced. 
Intake of nutrients and energy in week 2-15 of lactation of dairy cows $(n=16)$

\begin{tabular}{lrrrr}
\hline & & \multicolumn{1}{c}{ Tapioka } & \multicolumn{1}{c}{ Fat } & $\mathrm{P}<0.05$ \\
\hline Dry matter, & $\mathrm{kg} / \mathrm{d}$ & $20.85 \pm 0.91$ & $20.20 \pm 1.89$ & \\
NEL, & $\mathrm{MJ} / \mathrm{d}$ & $145.60 \pm 6.78$ & $148.10 \pm 14.5$ & \\
Crude fibre, & $\mathrm{kg} / \mathrm{d}$ & $2.94 \pm 0.25$ & $3.04 \pm 0.26$ & + \\
Starch, $\quad \mathrm{kg} / \mathrm{d}$ & $4.90 \pm 0.54$ & $3.22 \pm 0.61$ & + \\
Fat, $\quad \mathrm{kg} / \mathrm{d}$ & $0.53 \pm 0.08$ & $1.29 \pm 0.14$ & \\
Utilizable protein, $\mathrm{kg} / \mathrm{d}$ & $3.29 \pm 0.16$ & $3.39 \pm 0.27$ & + \\
Milk production, $\mathrm{kg} / \mathrm{d}$ & $38.00 \pm 6.49$ & $41.50 \pm 4.10$ & \\
Fat, $\quad \%$ & $4.36 \pm 0.56$ & $4.04 \pm 0.64$ & \\
Protein, $\quad \%$ & $3.19 \pm 0.34$ & $2.91 \pm 0.12$ & \\
Lactose, $\quad \%$ & $4.70 \pm 0.13$ & $4.71 \pm 0.12$ & \\
Milk efficiency & & & \\
FCM/NEL & 0.274 & 0.282 & \\
Protein/nXP & 0.368 & 0.356 & \\
Energy balance, NEL MJ/d & $-13.3 \pm 16.1$ & $-13.8 \pm 12.4$ & \\
\hline
\end{tabular}

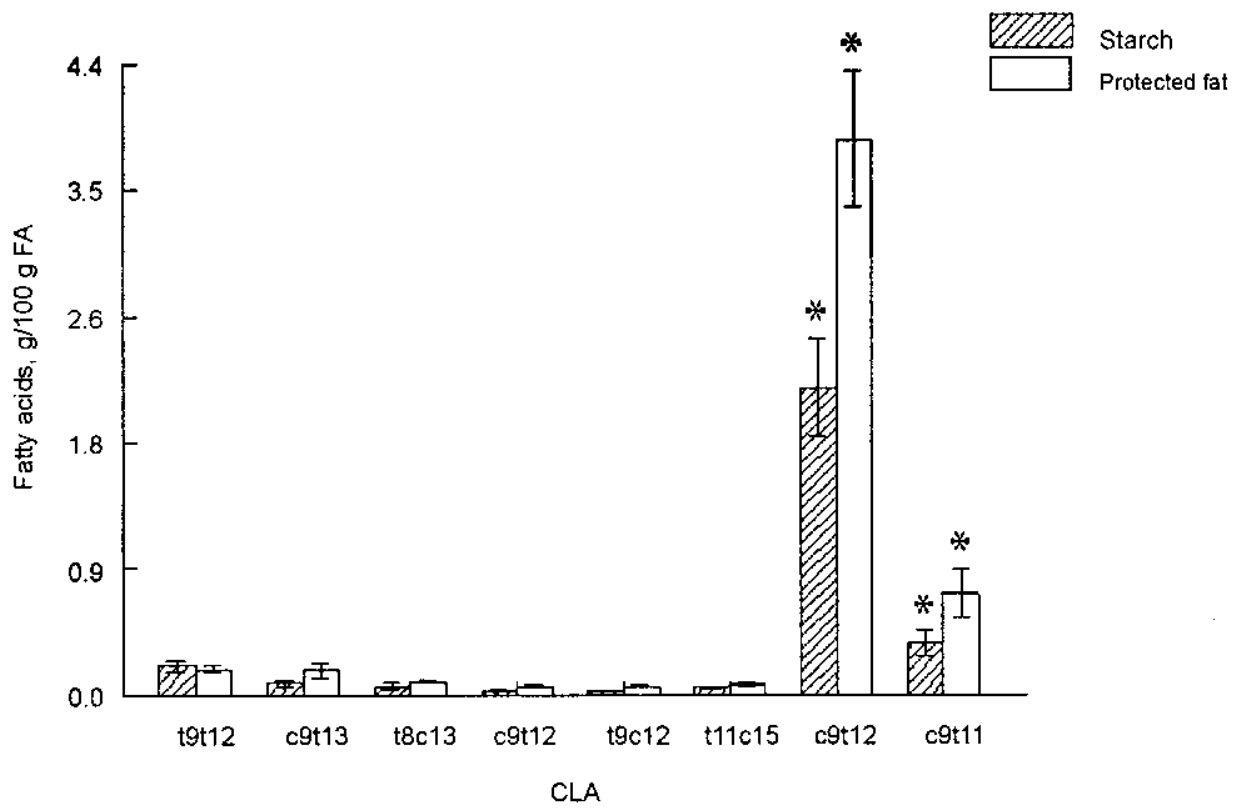

Figure 4. Isomers of $\mathrm{C}_{18: 2}$ in milk fat of dairy cows fed diets high in starch or protected fat rich in $\mathrm{C}_{18: 2}$ (Precht et al., 2001) 
VOIGT J., HAGEMEISTER H.

99
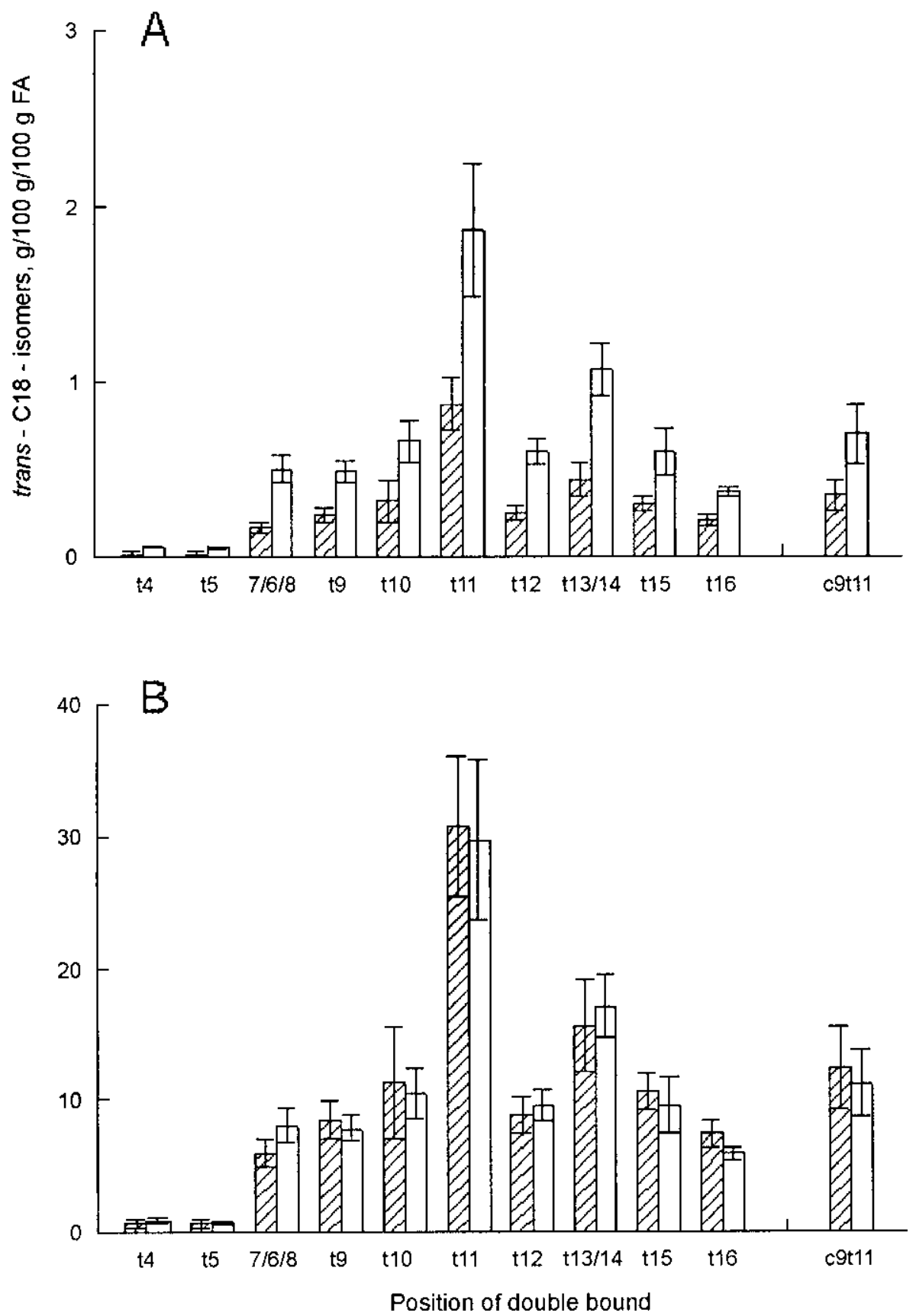

Figure 5. Content of trans isomers of $\mathrm{C}_{18}$ in milk fat of cows fed diets high in starch or protected fat A: $\mathrm{g} / 100 \mathrm{~g}$ fatty acids; B: $\mathrm{g} / 100 \mathrm{~g}$ trans $\mathrm{C}_{1 \mathrm{x}: 1}$-isomers (Precht et al., 2001) 


\section{REFERENCES}

Banks W., 1991. Milk fat - principles of dairy chemistry. J. Soc. Dairy Technol. 44, 31-32

Baumann D.E., Currie W.B., 1980. Partitioning of nutrients during pregnancy and lactation: a revicw of mechanism involving homeostasis and homeorhesis. J. Dairy Sci. 63, 1514-1529

Baumgard L.H., Corl B.A., Dwyer D.A., Saebø A., Bauman D.E., 2000. Identification of conjugated linoleic acid isomer that inhibits milk fat synthesis. Amer. J. Physiol. 278, R179-R184

Bassaganya-Riera J., Jontecillas-Magarzo R., Breegendahl K., Wannemuehler M.J., Zimmerman D.R., 2001. Effects of dietary conjugated linoleic acid in nursery pigs of dirty and clean environments on growth, empty body composition, and immune competence. J. Anim. Sci. 79, 714-721

Berg van den J.J., Cook N.E., Tribble D.L., 1995. Reinvestigation of the antioxidant properties of conjugated linoleic acid. Lipids 30, 599-605

Cant J.P., Qiao F., Toerien C.A., 1999. Regulation of mammary metabolism. In: E. Lobley, A. White, C. MacRae (Editors). Proceedings of Protein Metabolism and Nutrition. Wageningen Pers, Wageningen, pp. 203-219

Chan J.K., McDonald B.E., Gerrard J.M., Bruve V.M., Weaver B.J., Holub B.J., 1993. Effect of dietary alpha linolenic acid on platelet and plasma fatty acids and thrombosis. Lipids 28 , 811-817

Chilliard Y., Ferlay A., Mansbridge R.M., Doreau M., 2000. Ruminant milk fat plasticity: nutritional control of saturated, polyunsaturated, trans and conjugated fatty acids. Ann. Zootech. 49, 181205

Chouinard P.Y., Girard V., Brisson G.J., 1998. Fatty acid profile and physical properties of milk fat from cows fed calcium salts of fatty acids with varying unsaturation. J. Dairy Sci. 81, 471-481

Chouinard P.Y., Corneau L., Barbano D.M., Metzger L.E., Baumann D.E., 1999. Conjugated linoleic acids alter milk fatty acid composition and inhibit milk fat secretion in dairy cows. J. Nutr. $129,1579-1584$

Cook M.E., Park C.C., Pariza M., 1993. Immune modulation by altered nutrient metabolism: Nutritional control of immune-induced growth depression. Poultry Sci. 72, 1301-1305

Corl B.A., Baumgard L.H., Dwyer D.A., Griinari J.M., Phillips B.S., Bauman D.E., 2000. The role of delta 9 desaturase in the production of cis 9 , trans 11 CLA and other delta desaturated fatty acids in milk fat. J. Anim. Sci. 78, Suppl. 1, 164 (Abstr.)

Davis C.L., Brown R.E., 1970. Low-fat milk syndrome. In: A.T. Phillipson (Editor). Physiology of Digestion and Metabolism in the Ruminant. Oriel Press, Newcastle (UK), pp. 545-565

Desilets E., Pellerin D., Chouinard P.Y., 2000. Milk composition in Holstein cows fed canola oil in various form. J. Anim. Sci. 78, Suppl. 1, 278 (Abstr.)

Dhiman T.R., Anand G.R., Satter L.D., Pariza M.W., 1999. Conjugated linoleic acid content of milk from cows fed different diets. J. Dairy Sci. 82, 2146-2156

Dhiman T.R., MacQueen I. S., McMahon D. J., Walters J.L., Pariza M.W., 2000. Influence of conjugated linoleic acid (CLA) enriched cheesc on body composition. J Anim. Sci. 78, Suppl. 1, 167 (Abstr.)

Dhiman T.R., Satter L.D., Pariza M.W., Galli M.P., Albright K., Tolosa M.X., 2000. Conjugated linoleic acid (CLA) content of milk from cows. Offered diets rich in linoleic and linolenic acid. J. Dairy Sci. 83, 1016-1027

Dugan M.E.R., Aalhus J.L., Schaefer A.L., Kramer J.K.G., 1997. The effect of conjugated linoleic acid on fat to lean repartitioning and feed conversion in pigs. Can. J. Anim. Sci. 77, 723-725

Gaynor P.J., Erdman R.A., Teter B.B., Sampugna J., Capuco A.V., Waldo D.R., Hamosh M., 1994. Milk fat yield and composition during abomasal infusion of cis or trans octadecenoates in Holstein cows. J. Daịry Sci. 77, 157-165 
Gerson T., John A., King A.S.D., 1985. The effects of dietary starch and fibre in the in vitro rates of lipolysis and hydrogenation by sheep rumen digesta. J. Agr. Sci. 105, 27-30

Gerson T., John A., Sinclair B.R., 1983. The effect of dietary N on in vitro lipolysis and fatty acid hydrogenation in rumen digesta from sheep fed diets high in starch J. Agr. Sci. 101, 97-101

Griinari J.M., McGuire M.A., Dwyer D.A., Baumann D.E., Palmquist D.L., 1997. Role of insulin in the regulation of milk fat synthesis in dairy cows. J. Dairy Sci. 80, 1076-1084

Griinari J.M., Dwyer D.A., McGuire M.A., Baumann D.E., Palmquist D.L., Nurmela K.V.V., 1998. Trans-Octadecenoic acids and milk fat depression in lactating dairy cows. J. Dairy Sci. 81, 1251-1261

Griinari J.M., Baumann D.E., 1999. Biosynthesis of conjugated linoleic acid and its incorporation into meat and milk in ruminants. In: M.P. Yurawecz, M.M. Mossaba, J.K.G. Kramer, M.W. Pariza, G.J. Nelson (Editors). Advances in Conjugated Linoleic Acid research. Vol. II, Champaign, Illinois: AOCS Press, pp. 180-200

Griinari J.M., Corl B.A., Lacy S.H., Chouinard P.Y., Nurmela K.V.M., Baumann D.E., 2000. Conjugated linoleic cid is synthesized endogenously in lactating dairy cows by delta 9-desaturase. J. Nutr. 130, 2285-2291

Grummer R.R., 1991. Effect of feed on the composition of milk fat. J. Dairy Sci. 74, 3244-3257

Ha Y.L., Storkson J., Pariza M.W., 1990. Inhibition of benzo(a)pyrene-induced mouse forestomach neoplasia by conjugated dienoic derivatives of linoleic acid. Cancer Res. 50, 1097-1101

Hagemeister H., 1990. Fetteinsatz in der Milchviehfütterung unter besonderer Berücksichtigung der im Pansen entstehenden trans-Fettsäuren. Kiel. Milchwirt. Forschungsber. 42, 271-280

Hagemeister H., Precht D., Franzen M., Barth C.A., 1991. $\alpha$-linolenic acid transfer into milk fat and its clongation by cows. Fat. Sci. Tech. 93, 387-391

Herold P.M., Kinsella J.E., 1986. Fish oil consumption and decreased risk of cardiovascular disease: a comparison of findings from animal and human feeding trials. Amer. J. Clin. Nutr. 43, 566-598

Hodgson J.M., Wahlqvist M.L., Boxall J.A., Balazs N.D., 1996. Platelet trans fatty acids in relation to angiographically assessed coronary artery discase. Atherosclerosis $120,147-154$

Houseknecht K.L., Vanden Heuvel J.P., Moya-Camarena S.Y., Portocarrero C.P., Peck L.W., Nickel K.P., Belury A., 1998. Dietary conjugated linoleic acid normalizes impaire glucose tolerance in Zucker diabetic fatty $f a / f a$ rat. Biochim. Biophys. Acta 244, 678 682

Ip C., Chin S.F., Scimeca J.A., Pariza M.W., 1991. Mammary cancer prevention by conjugated dienoic derivative of linoleic acid. Cancer Res. 51, 6118-6124

Jiang J., Bjoerck L., Fonden R., Emanuelson M., 1996. Occurence of conjugated cis-9, trans11 -octadecadienoic acid in bovine milk: effects of feed and dietary regimen. J. Dairy Sci. 79, 438-445

Kelly M.L., Berry J.R., Dwyer D.A., Griinari J.M., Chouinard P.Y., van Amburgh M.E., Bauman D.E., 1998. Dietary fatty acid sources effect conjugated linoleic acid concentrations in milk from lactating dairy cows. J. Nutr. 128, 881-885

Kepler C.R., Tove S.B., 1967. Biohydrogenation of unsaturated fatty acids. J. Biol. Chem. 242, 5686-5692

Lacasse P., Kennelly J.J., Ahnadi C.E., 1998. Fecding protected and unprotected fish oil to dairy cows: Il Effect on milk fat composition. J. Anim. Sci. 76, Suppl. 1, 231 (Abstr.)

Lawson L., Kummerow F., 1979. Beta-oxidation of the coenzyme A esters of vaccenic, elaidic and petroselaidic acids of rat heart mitochondria. Lipids 14,501-503

Lin Y., Kreeft A., Schuurbiers J.A., Draijer R., 2001. Different effects of conjugated linoelic acid isomers on lipoprotein lipase activity in 3T3-LI adipocytes. J. Nutr. Biochem. 12, 183-189

McNamara J.P., Harrison J.H., Klincaid R.L., Waltner S.S., 1995. Lipid metabolism in adipose tissue of cows fed high fat diets during lactation. J. Dairy Sci. 78, 2782-2796 
Mensink R.P., Katan B., 1992. Effect of dictary fatty acids on serum lipids and lipoproteins. Arterioscler. Thromb. 12, 911-919

Mensink R.P., Zock P.L., 1998. Lipoprotein metabolism and trans fatty acids. In: J.L. Sebedio, W.W. Christi (Editors). Trans Fatty Acids in Human Nutrition. The Oily Press, Ltd. Dundec (Scotland), pp. 217-234

Molkentin J., 2000. Occurence and biochemical characteristics of natural bioactive substances in bovine milk lipids. Brit. J. Nutr. 84, Suppl. 1, 47-53

Nicolosi R.J., Rogers E.J., Kritschevski D., Scimeca J.A., Huth P., 1997. Dietary conjugated linoleic acid reduces plasma lipoproteins and early aortic atherogenesis in hypercholesterolemic hamsters. Artery 22, 266-277

Noakes M., Nestel P.J., Clifton P.M., 1996. Modifying the fatty acid profile of dairy products through feedlot technology lowers plasma cholesterol of human consuming the product. Amer. J. Clin. Nutr. 63, 42-46

Noble R.C., Moore J.H., Harfoot C.G., 1974. Observations on the pattern on biohydrogenation of esterified and unesterified linoleic acid in the rumen. Brit. J. Nutr. 31, 99-108

Park Y., Albright K.J., Lui W., Storkson J.M., Cook M.E., Pariza M.W., 1997. Effect of conjugated linoleic acid on body composition in mice. Lipids 32, 853-858

Park Y.S., Behre R.A., McGuire M.A., Shultz T.D., McGuire M.K., 1997. Dictary conjugated linoleic acid (CLA) and CLA in human milk. FASEB J. 11, 239 (Abstr.)

Parodi P.W., 1997. Cows' milk fat components as potential anticarcinogenic agents. J. Nutr. 127, $1055-1060$

Parodi P.W., 1999. Conjugated linoleic acid and other anticarcinogenic agents of bovine milk fat. J. Dairy Sci. 82, 1339-1349

Piperova L.S., Teter B.B., Sampugna J., Yurawecz M.P., Bruckental I., Erdman R.A., 2000. Dietary milk fat depression and trans -18:1 and CLA isomer distribution in milk of lactating cows. J. Anim. Sci. 78, Suppl. 1/J. Dairy Sci. 83, Suppl. 1, 277 (Abstr.)

Precht D., Molkentin J., 1997. Effect of feeding on conjugated cis-9, trans-11 octadecadienoic acid and other isomers of linoleic acid in bovine milk fats. Nahrung 41, 330-335

Precht D., Molkentin J., 1998. Correlations of anticarcinogenic conjugated linoleic acid with other $\mathrm{C} 18$ fatty acids in German bovine milk fat. Berichte der Bundesforschungsanstalt für Ernährung, BFE-R-98-02

Precht D., Voigt J., Hagemeister H., Kanitz W., 2001. Influence of fat enriched with dietary linoleic acid on the milk fat quality of high-yielding cows post partum. Europ. J. Lipid Sci. Tech. (presented)

Reaven P., Parthasarathy S., Grasse B.J., Miller E., Almazan F., Mattson F.H., Khoo J.C., Steinberg D., Witztum J.L., 1991. Feasibility of using an oleate-rich diet to reduce the susceptibility of low-density lipoprotein to oxidative modification in humans. Amer. J. Clin. Nutr. 54, 701-706

Rosenthal M.D., Doloresco M.A., 1984. The effects of trans fatty acids on fatty acid D5-desaturation by human skin fibrolasts. Lipids 19, 869-874

Salminen I., Mutanen M., Jauhiainen M., Aro A., 1998. Dietary trans fatty acids increase conjugated linoleic acid levels in human serum. J. Nutr. Biochem. 9, 93-98

Santoro J.E., Palmquist D.E., Roehring K.L., 2000. Trans-vaccenic acid is desaturated to conjugated linoleic acid in mice. J. Nutr. 130, 208-215

Solomon R., Chase L.E., Ben-Ghedalla D., Baumann D.E., 2000. The effect of nonstructural carbohydrate and addition of full fat extruded soyabeans on the concentration of conjugated linoleic acid in the milk fat of dairy cows. J. Dairy Sci. 83, 1322-1329

Sutton J.D., 1989. Alterin milk composition by feeding. J. Dairy Sci. 72, 2801-2814 
van Greevenbroek M.M.J., Robertus-Teunissen M.G., Erkelens D.W., de Bruin T.W.A., 1998. Lipoprotein secretion by intestinal Caco-2 cells is affected differently by trans and cis unsaturated fatty acids: effects of carbon chain length and position of the double bond. Amer. J. Clin. Nutr. $68,561-567$

Wagner K., Lebzien P., Jahreis G., Flachowsky G., 1999. Influence of differently hydrogenated soybean oils on trans-fatty acids in duodenal chyme and milk fat. S. Afr. J. Sci. 29, 260

Willett W.C., Stampfer J.M., Manson J.E., Colditz G.A., Speizer F.E., Rosner B.A., Sampson L.A., Hennekeens C.H., 1993. Intake of trans fatty acids and risk of coronary heart disease among women. Lancet 341, 581-586

Williams C.M., 2000. Dietary fatty acids and human health. Ann. Zootech. 49, 165-180

\section{STRESZCZENIE}

\section{Wplyw paszy na zawartość pożądanych kwasów tluszczowych w mleku krów}

Składnikami mleka, które mają znaczenie dla podniesienia zdrowotności i zapobiegania różnym schorzeniom u ludzi, są pośrednic produkty biouwodomienia wielonienasyconych kwasów tłuszczowych w żwaczu bydła. Produkty mleczne są głównym żródłem sprzężonych kwasów linolowych (CLA) w diecie ludzi. Udowodniono, że CLA mogą powstrzymywać procesy rakotwórcze, modulować system odpornościowy i zapobiegać otyłości, zmniejszając ryzyko miażdżycy i cukrzycy.

Wykazano, że izomeryczna forma trans kwasów thuszczowych ma niekorzystny wpływ na poziom cholesterolu LDL. Wobec powyższego należy dążyć do podwyższania w mleku zawartości wielonienasyconych kwasów tłuszczowych i CLA i jednoczesnego obniżania poziomu kwasów thuszczowych trans -9 i trans- $10 \mathrm{C}_{18: 1}$.

Cel ten nie jest latwy do osiągnięcia ze względu na wysoką korelację $(r=0,88)$ między CLA i sumą wszystkich izomerów trans kwasów tłuszczowych w tłuszczu mleka. Należy opracować nowe strategie żywienja przeżuwaczy, dających mleko, uwzględniających niezależne czynniki regulujące zawartość różnych izomerów C:18, jak żywienie pastwiskowe, stosunek pasz treściwych do objętościowych, stosowanie chronionych olejów roślinnych oraz dobór krów wykazujących małą wrażliwość na czynniki modyfikujące tłuszcz mleka. 